\title{
UJI COBA PENANGKAPAN PADA RUMPON PORTABLE DI PERAIRAN PALABUHANRATU
}

\section{(CATCHING TRIAL AROUND PORTABLE FISH AGGREGATING DEVICE AT PALABUHANRATU)}

\author{
Roza Yusfiandayani ${ }^{1,2}$, Indra Jaya ${ }^{2}$, Mulyono S. Baskoro ${ }^{2}$ \\ ${ }^{1}$ Corresponding author \\ ${ }^{2}$ Departemen Pemanfaatan Sumberdaya Perikanan \\ Fakultas Perikanan dan Ilmu Kelautan, Institut Pertanian Bogor \\ E-mail: ocha_roza@yahoo.com
}

\begin{abstract}
Fish Aggregating Device (FAD) usually used by small scale and large scale fishermen in Indonesia are FAD shallow and deep sea water which fix in the water. Efectivities and eficiency research activity about portable $F A D$ in the water to catch thunnus spp. and skipjack have never been done in Indonesia. Need the research about portable FAD to catch thunnus spp. and skipjack in the water. This research can strong National Inovation System with portable FAD to belp the fishermen in fishing operation methods. Catching trial around portable FAD by using experimental fishing used troll lines and hand lines. The purpose of this research are to know the number and composition of fish around portable FAD and to know stomacth content and plankton in the water.
\end{abstract}

Keywords: Portable FAD, sustainable, thunnus and skipjack

\begin{abstract}
ABSTRAK
Rumpon yang biasa digunakan oleh nelayan dan pengusaha di seluruh Indonesia adalah rumpon yang dipasang menetap di suatu perairan, sehingga tidak dapat dipindah-pindah ke perairan lain. Sejauh ini di Indonesia belum pernah dilakukan penelitian tentang efektivitas dan efisiensi rumpon yang dapat dibawa kemana-mana dan mudah dipindahkan (portable) untuk menangkap ikan tuna dan cakalang. Oleh karena itu diperlukan penelitian tentang rumpon portable untuk menangkap ikan tuna dan cakalang. Penelitian ini diharapkan dapat memperkuat Sistem Inovasi Nasional dengan adanya rumpon portable yang memudahkan nelayan dalam operasi penangkapan ikan.Uji coba penangkapan di rumpon portable dilakukan dengan experimental fishing menggunakan alat tangkap pancing tonda dan pancing gajrut. Tujuan dari penelitian ini adalah mengetahui komposisi dan jumlah ikan yang berkumpul di rumpon portable serta mengetahui isi perut ikan dan plankton yang terdapat di perairan.
\end{abstract}

Kata kunci: Rumpon portable, berkelanjutan, tuna dan cakalang

\section{PENDAhuluan}

\subsection{Latar Belakang}

Rumpon atau Fish Aggregating Device (FAD) adalah salah satu jenis alat bantu penangkapan ikan yang dipasang di laut, baik laut dangkal maupun laut dalam. Pemasangan tersebut dimaksudkan untuk menarik gerombolan ikan agar berkumpul di sekitar rumpon, sehingga ikan mudah untuk ditangkap. Konstruksi rumpon menyerupai pepohonan yang dipasang atau ditanam pada kedalaman tertentu di suatu tempat di perairan laut yang berfungsi sebagai tempat berlindung, mencari makan, memijah dan berkumpulnya ikan. Metode pemasangan dari rumpon laut dangkal dan rumpon laut dalam hampir sama, perbedaannya hanya pada daerah pemasangan serta bahan yang digunakan.

Secara garis besar rumpon, baik rumpon laut dalam maupun rumpon laut dangkal pada prinsipnya terdiri dari empat komponen utama, yaitu: (1) pelampung atau float; (2) tali panjang atau rope; (3) pemikat ikan atau atractor dan (4) pemberat atau sinker. Rumpon yang portable merupakan rumpon yang tidak diletakkan secara tetap di perairan, tetapi diletakkan pada saat akan melakukan kegiatan penangkapan di daerah penangkapan ikan tersebut, sehingga ketika tidak digunakan, dapat dibawa, dipindahkan ke daerah lain atau di simpan sampai dilakukan operasi penangkapan ikan selanjutnya. 
Penelitian ini didasari oleh produksi perikanan tuna dan cakalang berbasis rumpon yang terus menurun dengan ketersediaan sumberdaya yang terbatas dan juga daerah penangkapan tuna dan ikan cakalang yang semakin jauh, sementara itu upaya untuk pemanfaatan semakin meningkat sehingga perlu dipandang dengan adanya pengelolaan yang baik dan juga berkelanjutan. Berdasarkan permasalahan tersebut di atas maka dianggap perlu untuk mengkaji pembuatan rumpon portable yang mudah dibawa kemana-mana dan tingkat kelayakan pemanfaatan rumpon dan optimalisasi armada penangkapan yang beroperasi di sekitar rumpon agar produktivitas optimum dapat terjaga.

Dasar pertimbangan yang menjadi kerangka pemikiran adalah peningkatan pemasangan rumpon yang menyebabkan peningkatan aktivitas penangkapan di lokasi penelitian yang mengakibatkan terjadinya penurunan hasil produksi sehingga dianggap perlu adanya pengelolaan pemanfaatan secara optimal dengan menitik beratkan pada masalah jumlah rumpon dan alat tangkap yang beroperasi di sekitar rumpon.

Oleh karena itu, pengkajian terhadap rumpon portable untuk pengelolaan ikan tuna dan cakalang secara berkelanjutan dalam mengantisipasi implementasi Code of Conduct for Responsible Fisheries ini perlu dilakukan. Rumpon portable memiliki keuntungan: 1) mudah dibawa dan ditempatkan di perairan; 2) dapat menjangkau ke perairan yang lebih jauh tanpa memerlukan biaya yang besar; dan 3) memudahkan operasi penangkapan ikan. Penelitian dengan ini diharapkan dapat memperkuat Sistem Inovasi Nasional dengan adanya rumpon portable yang memudahkan nelayan, informasi geospasial daerah penangkapan ikan yang bermanfaat bagi armada penangkapan serta informasi mengenai carrying capacity rumpon di suatu daerah penangkapan ikan sebagai komponen informasi dasar yang strategis dalam membantu merumuskan kebijakan pengelolaan berkelanjutan sumberdaya ikan.

\subsection{Tujuan}

(1) Mengetahui komposisi dan jumlah ikan tuna dan cakalang yang berkumpul di rumpon portable.
(2) Mengetahui isi perut ikan dan plankton yang terdapat di perairan.

\section{METODOLOGI PENELITIAN}

\subsection{Waktu dan Tempat}

Kegiatan pengambilan data menggunakan rumpon portable dilakukan di Palabuhanratu selama 7 hari mulai tanggal 20-27 Agustus 2013 (Gambar 1). Waktu pengambilan data dilakukan pada pagi, siang dan sore hari.

\subsection{Alat dan Bahan}

Alat dan bahan yang digunakan dalam penelitian ini dibagi menjadi peralatan yang digunakan untuk uji coba lapang serta alat dan bahan yang digunakan dalam pembuatan rumpon portable. Peralatan yang digunakan untuk uji coba lapang adalah kapal, plankton net, tali tambang, GPS, hand camera, alat tangkap yaitu pancing gajrut dan pancing tonda untuk menangkap ikan tuna dan cakalang. Peralatan yang digunakan tersebut pengadaannya dilakukan secara langsung dari laboratorium dan dari nelayan bersangkutan yang ikut membantu penelitian ini (Tabel 1).

Kegiatan yang dilakukan mencakup dua tahapan, yakni pada skala laboratorium dan uji coba alat Electric Fish Attractor (EFA) di lapangan. Skala laboratorium kegiatan yang dilakukan yaitu membuat rancangan dan perakitan komponen-komponen elektronik pada EFA serta gelombang suara dengan menggunakan software matlab yang dipasang dengan frekuensi rendah $(10-1000 \mathrm{~Hz})$ dan frekuensi sedang $(1000-20.000 \mathrm{~Hz})$. Skala pengujian EFA dilakukan di teluk Palabuhanratu, Sukabumi Jawa Barat pada stasiun yang berbeda setiap harinya.

\section{HASIL DAN PEMBAHASAN}

\subsection{Rumpon portable}

Desain rumpon portable yang telah berhasil dibuat ada 2 yaitu rumpon portable menggunakan pipa paralon (Gambar 2) dan rumpon portable dari kayu manglid (Gambar 3).

Percobaan laut rumpon portable dilakukan di Pelabuhanratu pada tanggal 21 Agustus sampai dengan 27 Agustus. Proses penelitian diawali dengan peng- 
angkatan rumpon portable yang telah diletakkan di kolam percobaan Stasiun Lapang Kelautan Fakultas Perikanan dan Ilmu Kelautan Institut Pertanian Bogor. Tahapan selanjutnya adalah memobilisasi rumpon portable dan barang bawaan menuju kapal di Palabuhanratu Dermaga 2. Pemberangkatan menuju daerah pengoperasian dilakukan pada pukul 10.15 dan tiba pada pukul 15.25.
Pada pukul 16.00 dilakukan proses setting rumpon portable pada posisi $\mathrm{S}$ $07^{\circ} 02^{\prime} 23,5^{\prime \prime}$ E $106^{\circ} 25^{\prime} 52,1^{\prime \prime}$ dengan urutan tahapan sebagai berikut:

1. menurunkan pemberat,

2. menurunkan tali utama,

3. menurunkan atraktor,

4. menurunkan rangka atau badan rumpon dan pelampung.

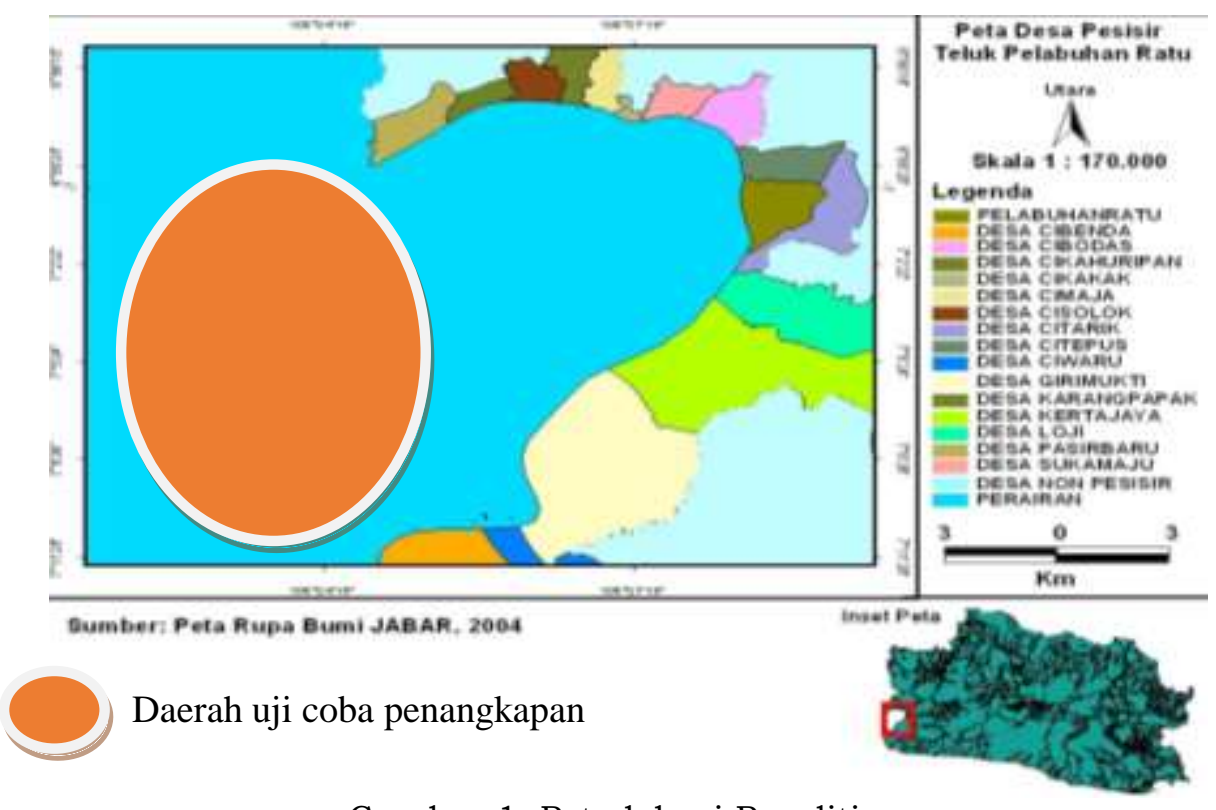

Gambar 1. Peta lokasi Penelitian

Tabel 1. Alat dan bahan yang digunakan dalam pembuatan rumpon portable

\begin{tabular}{lll}
\hline No. & Alat & Bahan \\
\hline 1 & Pipa $\varphi$ 0.5 mm & Resin \\
2 & Jaring PE & Dempul \\
3 & Gergaji & Lem pipa dan paralon \\
4 & Sambungan pipa T, L & Cat dan thinner \\
5 & Tali PE 4 mm & Kabel \\
6 & Jerigen 301 & Coban \\
7 & Roben ties nylon & Pemberat \\
8 & Komputer/laptop & Kayu manglid \\
\hline
\end{tabular}

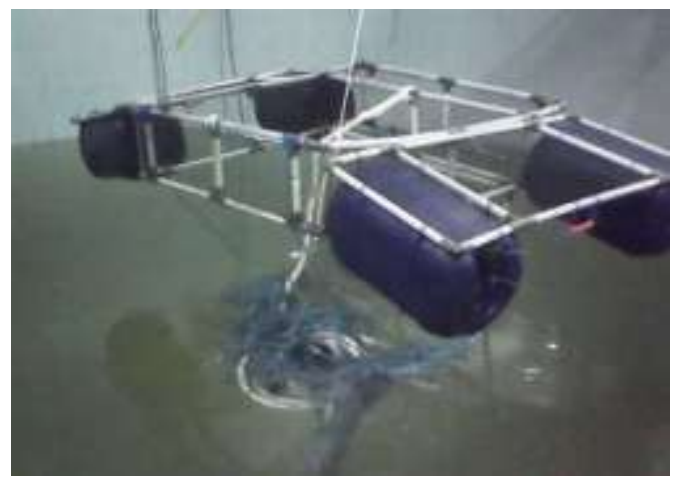

Gambar 2. Rumpon portable pipa paralon 


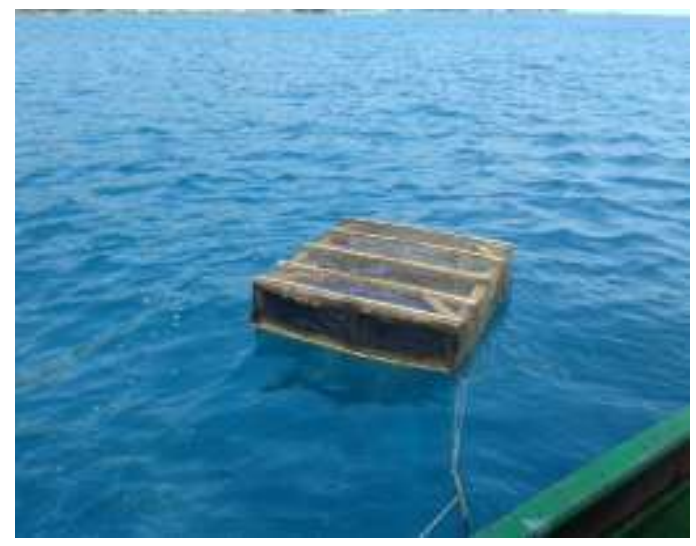

Gambar 3. Rumpon portable kayu manglid

Rumpon portable didiamkan diperairan selama 4 jam dengan rincian pada saat penurunan dilakukan pengambilan data plankton dan arus. Proses eksplorasi ikan dilakukan setelah rumpon portable diletakkan selama 2 jam dan bersamaan dengan itu dilakukan pengambilan data plankton yang kedua. Tahapan yang dilakukan dalam pengambilan data plankton diawali dengan mengikat pemberat pada tabung plankton net dan mengikat tali pada gagang plankton net. Tahapan selanjutnya ialah penurunan plankton net sedalam 5 meter didekat rumpon portable dan dilakukan pengangkatan. Tahapan selanjutnya ialah peletakkan hasil plankton net ke dalam botol film dan diberi lugol sebanyak 2 tetes. Tahapan pengukuran arus dilakukan dengan metode lagrangian, yakni dengan mengukur waktu dari perpindahan benda apung dari satu titik ke titik yang lainnya. Pada penelitian ini benda apung yang digunakan ialah karet yang diukur waktu perpindahannya sepanjang $6,08 \mathrm{~m}$ dan dilakukan pengolahan data menggunakan rumus kecepatan $(\mathrm{V}=\mathrm{S} \times \mathrm{t})$. Proses eksplorasi pada tahapan setting yang pertama ini dilakukan dengan menggunakan hand line atau pancing ulur dengan metode copping, yakni metode memancing dengan menggunakan umpan buatan berupa cekungan sendok makan yang secara aktif ditarik dan disentak. Pada tahapan setting ini ikan yang berhasil ditangkap sebanyak 2 ekor. Tahapan pengangkatan rumpon portable dilakukan setelah diletakkan selama 4 jam. Tahapan pengangkatan rumpon portable dilakukan dengan urutan sebagai berikut:
1. menaikkan atraktor,

2. menaikkan tali utama,

3. menaikkan pemberat,

4. menaikkan rangka atau bagan rumpon dan pelampung.

Tanggal 22-27 Agustus 2013 dilakukan tiga kali setting dengan dua alat tangkap yang berbeda. Setting pertama dilakukan pada pukul 05.00 WIB, setting kedua dilakukan pada pukul 12.00 WIB dan setting ketiga pada pukul 16.00 WIB. Setting pertama dan kedua dilakukan dengan tahapan menggunakan electric fish attractor (EFA) yakni dengan mengubah dari frekuensi sedang (1000$20.000 \mathrm{~Hz}$ ) ke frekuensi rendah (10-1000 $\mathrm{Hz}$ ). Metode penangkapan dengan menggunakan pancing tonda, yakni dengan mengelilingi rumpon portable sekaligus menarik rangkaian pancing yang yang diikat di belakang kapal. Setting ketiga dilakukan pukul 16.00 WIB dilakukan proses setting yang ketiga dengan tahapan yang sama seperti setting sebelumnya, perbedaannya terdapat pada penggunaan EFA dari frekuensi frekuensi rendah $(10-1000 \mathrm{~Hz})$ ke frekuensi sedang (1000-20.000 Hz). Metode penangkapan dengan menggunakan pancing ulur.

Data hasil perhitungan kecepatan arus pada saat setting rumpon portable digambarkan dalam kurva fluktuasi arus pada Gambar 4.

Komposisi hasil tangkapan yang diperoleh saat melakukan uji coba penangkapan yang berlangsung mulai tanggal 21 Agustus 2013 sampai dengan 27 Agustus 2013 menghasil berbagai macam spesies ikan (Gambar 5). Hasil tangkapan yang diperoleh menghasilkan target utama penangkapan, yaitu tuna sirip 
kuning (Thunnus Albacares), tongkol (Auxis Thazard), dan kuwe (Caranx Sexfasciatus). Hasil tangkapan yang mendominasi, yaitu layur (Trichiurus $s p$.) yang didapatkan sebanyak 116 ekor.

Alat tangkap yang digunakan adalah pancing ulur (Gambar 6) dan pancing tonda (Gambar 7).

Hasil tangkapan uji coba rumpon portable di perairan dapat di lihat pada Tabel 2. Hasil tangkapan pada tanggal 21-27 Agustus berfluktuasi (Gambar 811). Tuna berhasil didapatkan pada tanggal 24 Agustus sebanyak 2 ekor.
Berdasarkan data harian yang di buat pada diagram terlihat persentasi keseluruhan dan persentasi harian ikan yang tertangkap. Persentasi keseluruhan ikan hasil tangkapan tertinggi adalah ikan layur sebesar $63 \%$ dari total 184 ekor ikan hasil tangkapan, kurisi $10 \%$, serepet $7 \%$, tongkol kue dan semar $4 \%$, jambangan terong-terong dan kerapu hanya $2 \%$, dan sisanya masing-masing $1 \%$.

Komposisi hasil yang didapatkan, bahwa setiap ikan yang tertangkap dalam isi perutnya terdapat plankton yang terdapat pula pada perairan (Tabel 1, Tabel 2 dan Tabel 3).

\section{Data fluktuasi arus}

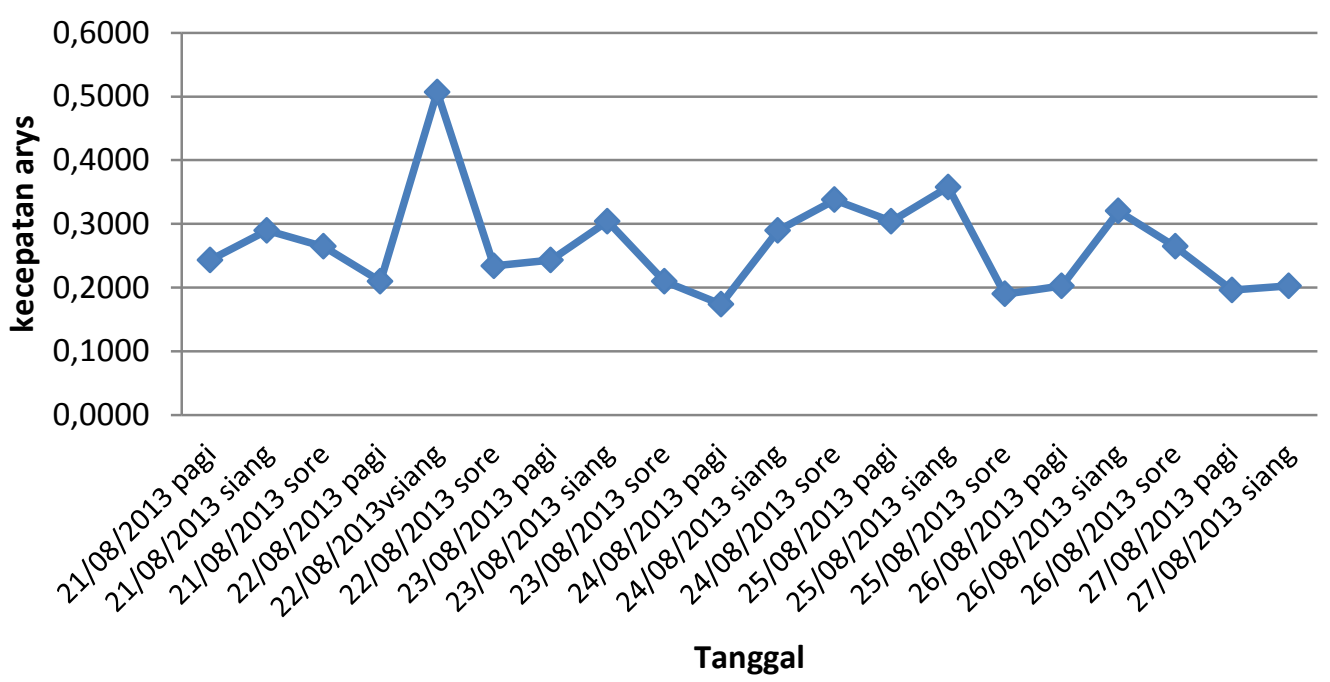

Gambar 4. Kurva fluktuasi arus per setting rumpon portable

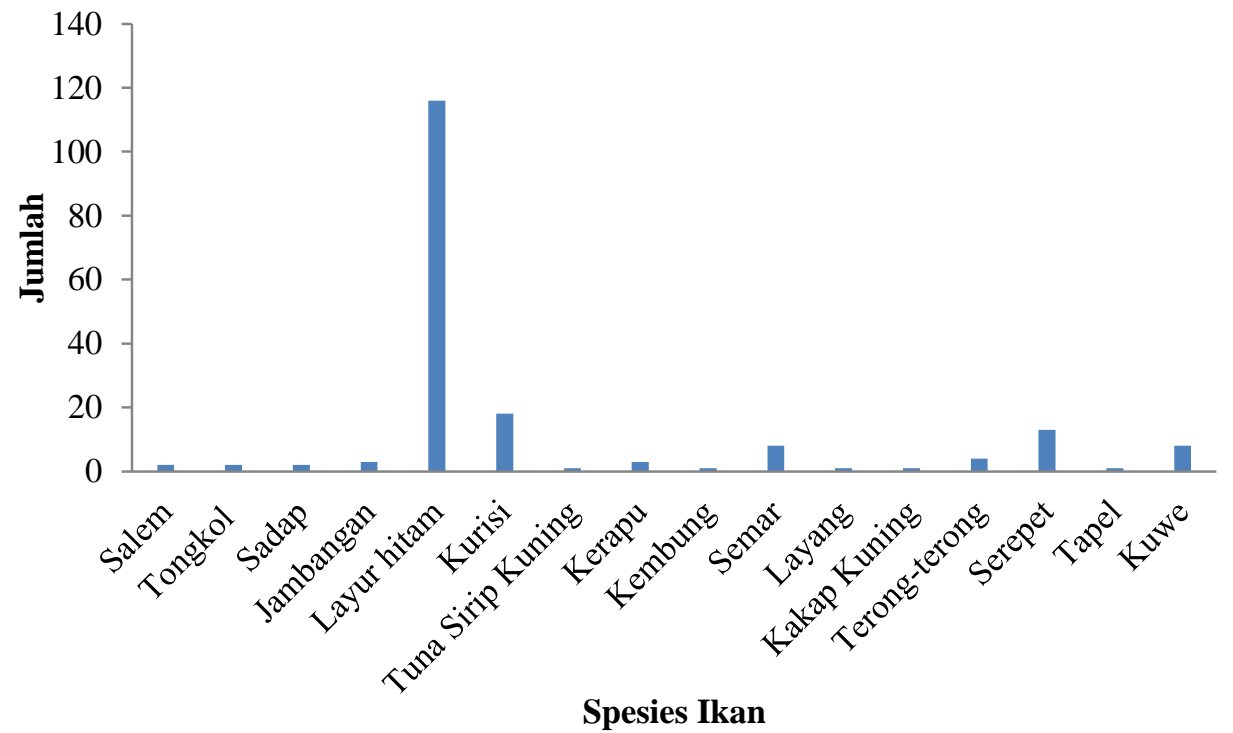

Gambar 5. Komposisi hasil tangkapan 


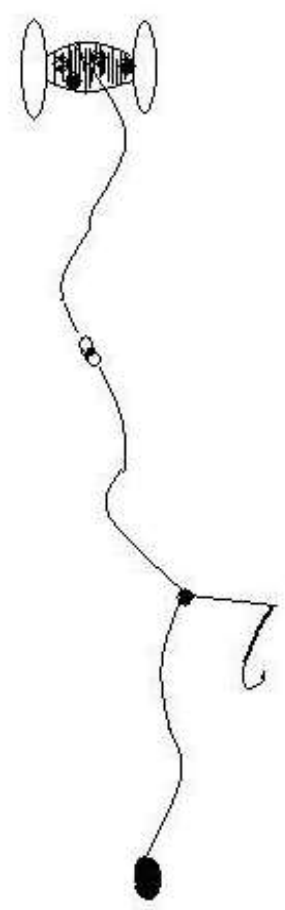

Gambar 6. Konstruksi pancing gajrut

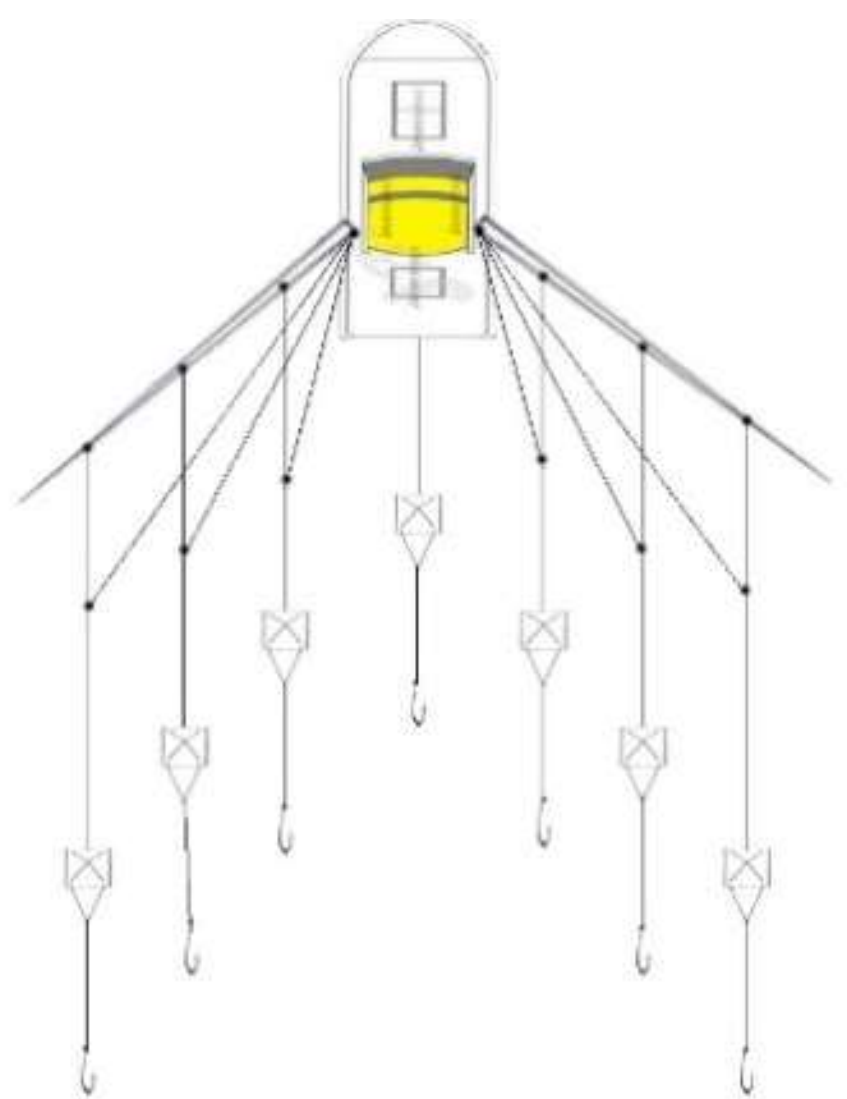

Gambar 7. Pancing Tonda 
Tabel 2. Jumlah Hasil Tangkapan

\begin{tabular}{l|l|l}
\hline No. & Spesies Ikan & Jumlah (Ekor) \\
\hline 1 & Salem & 2 \\
2 & Tongkol Keke & 2 \\
3 & Sadap & 2 \\
4 & Jambangan & 3 \\
5 & Layur Hitam & 116 \\
6 & Kurisi & 18 \\
7 & Tuna & 1 \\
8 & Kerapu & 3 \\
9 & Kembung & 1 \\
10 & Semar & 8 \\
11 & Layang & 1 \\
12 & Kakap Kuning & 1 \\
13 & Terong-Terong & 4 \\
14 & Serepet & 13 \\
15 & Tapel & 1 \\
16 & Tongkol Kue & 8 \\
\hline
\end{tabular}

21 Agustus 2013

$12 \%$

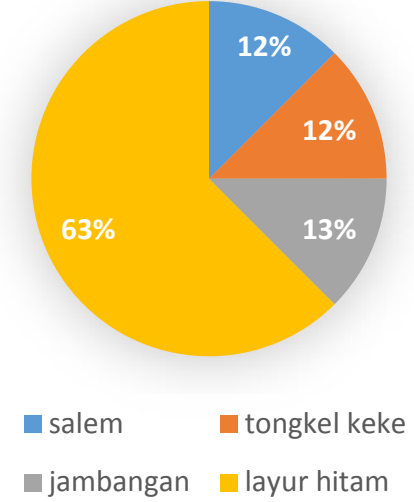

22 Agustus 2013

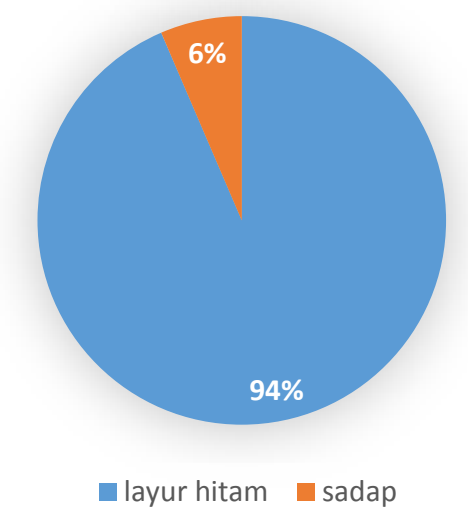

Gambar 8. Komposisi hasil tangkapan pada tanggal 21 Agustus dan 22 Agustus

23 Agustus 2013

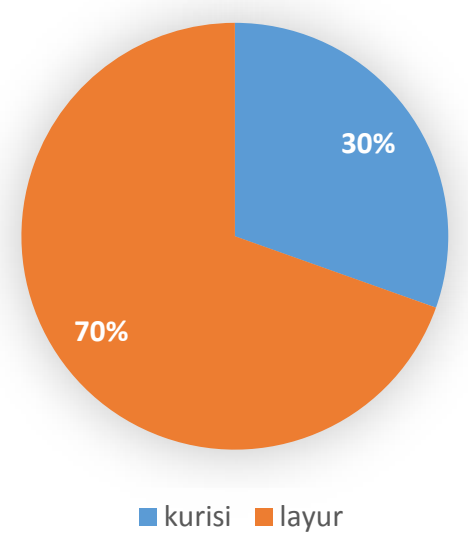

24 Agustus 2013

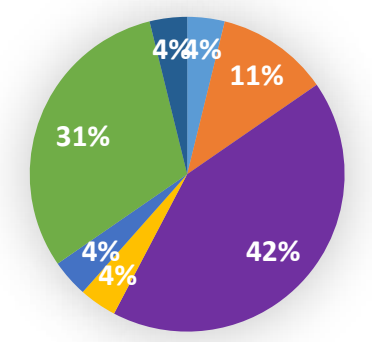

- tuna kerapu $\quad$ kurisi

- jambangan $\mathbf{a}$ kembung $\mathbf{s e m a r}$

- layang

Gambar 9. Komposisi hasil tangkapan pada tanggal 23 Agustus dan 24 Agustus 
25 Agustus 2013

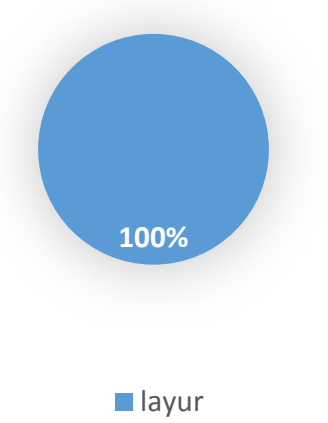

26 Agustus 2013

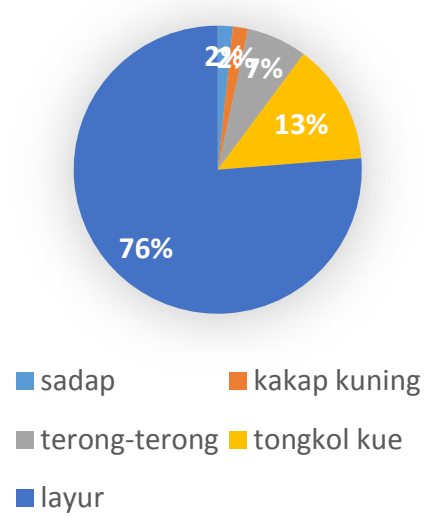

Gambar 1. Komposisi hasil tangkapan pada tanggal 25 Agustus dan 26 Agustus

27 Agustus 2013

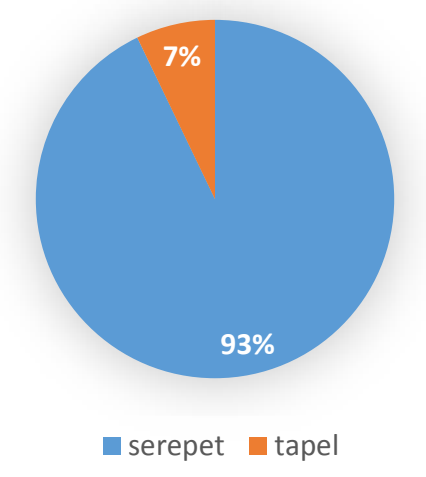

Gambar 2 Komposisi hasil tangkapan pada tanggal 27 Agustus

Tabel 1. Plankton yang berada di perairan dan di isi perut ikan pada penangkapan pagi hari

\begin{tabular}{l|c|c|c|c}
\hline \multirow{2}{*}{\multicolumn{1}{c|}{ Genus }} & \multirow{2}{*}{ Perairan } & \multicolumn{3}{|c}{ Spesies Ikan } \\
\cline { 3 - 5 } & & Kuwe & Kurisi & Salem \\
\hline Rhizosolenia & $\mathrm{v}$ & $\mathrm{v}$ & $\mathrm{v}$ & $\mathrm{v}$ \\
Leptocilindricus & $\mathrm{v}$ & - & $\mathrm{v}$ & - \\
Tintinnopsis & $\mathrm{v}$ & - & $\mathrm{v}$ & - \\
Skeletonema & - & - & $\mathrm{v}$ & - \\
Pleurosigma & $\mathrm{v}$ & $\mathrm{v}$ & $\mathrm{v}$ & - \\
Nitzschia & $\mathrm{v}$ & - & - & - \\
Guinardia & $\mathrm{v}$ & $\mathrm{v}$ & - & - \\
Coscinodiscus & $\mathrm{v}$ & $\mathrm{v}$ & - & - \\
Halosplaera & - & $\mathrm{v}$ & - & - \\
\hline
\end{tabular}


Tabel 2. Plankton yang berada di perairan dan di isi perut ikan pada penangkapan siang hari

\begin{tabular}{|c|c|c|c|c|}
\hline \multirow{2}{*}{ Genus } & \multirow{2}{*}{ Perairan } & \multicolumn{3}{|c|}{ Spesies Ikan } \\
\hline & & Kerapu & Kurisi & Salem \\
\hline Rhizosolenia & $\mathrm{v}$ & $\mathrm{v}$ & $\mathrm{v}$ & $\mathrm{v}$ \\
\hline Leptocylindricus & $\mathrm{V}$ & $\mathrm{v}$ & $\mathrm{v}$ & $\mathrm{v}$ \\
\hline Tintinnopsis & $\mathrm{v}$ & - & - & $\mathrm{v}$ \\
\hline Skeletonema & $\mathrm{v}$ & - & - & - \\
\hline Pleurosigma & $\mathrm{v}$ & $\mathrm{v}$ & - & $\mathrm{v}$ \\
\hline Nitzschia & $\mathrm{V}$ & $\mathrm{v}$ & - & - \\
\hline Guinardia & $\mathrm{v}$ & - & - & - \\
\hline Bacillaria & $\mathrm{v}$ & - & - & - \\
\hline Lauderina & - & $\mathrm{v}$ & - & - \\
\hline Polykrikos & - & $\mathrm{v}$ & - & - \\
\hline Ceratium & - & $\mathrm{v}$ & $\mathrm{v}$ & - \\
\hline Prorocentrum & $\mathrm{v}$ & - & - & - \\
\hline
\end{tabular}

Tabel 3. Plankton yang berada di perairan dan di isi perut ikan pada penangkapan malam hari

\begin{tabular}{|c|c|c|c|c|c|c|}
\hline \multirow{2}{*}{ Genus } & \multirow{2}{*}{ Perairan } & \multicolumn{5}{|c|}{ Spesies Ikan } \\
\hline & & Kurisi & Kue & Layur & Layang & Tuna \\
\hline Rhizosolenia & $\mathrm{v}$ & $\mathrm{v}$ & $\mathrm{v}$ & $\mathrm{v}$ & $\mathrm{v}$ & $\mathrm{v}$ \\
\hline Leptocylindricus & $\mathrm{v}$ & $\mathrm{v}$ & $\mathrm{v}$ & $\mathrm{v}$ & $\mathrm{v}$ & $\mathrm{v}$ \\
\hline Tintinnopsis & $\mathrm{v}$ & $\mathrm{v}$ & $\mathrm{v}$ & $\mathrm{v}$ & $\mathrm{v}$ & $\mathrm{v}$ \\
\hline Skeletonema & - & $\mathrm{v}$ & - & - & - & $\mathrm{v}$ \\
\hline Pleurosigma & $\mathrm{v}$ & - & $\mathrm{v}$ & $\mathrm{v}$ & - & - \\
\hline Nitzschia & $\mathrm{v}$ & - & $\mathrm{v}$ & - & - & - \\
\hline Guinardia & $\mathrm{v}$ & $\mathrm{v}$ & - & $\mathrm{v}$ & - & - \\
\hline Coscinodiscus & - & - & $\mathrm{v}$ & $\mathrm{v}$ & - & - \\
\hline Bacillaria & - & - & - & $\mathrm{v}$ & - & - \\
\hline
\end{tabular}

\section{KESIMPULAN DAN SARAN}

\subsection{Kesimpulan} lah:

Kesimpulan dari penelitian ini ada-

1. Hasil tangkapan dengan menggunakan pancing gajrut (pancing ulur) mendapatkan tuna sirip kuning (yellowfin tuna) sejumlah 2 ekor dengan ukuran panjang $30 \mathrm{~cm}$ dengan berat $40 \mathrm{~kg}$, sedangkan alat tangkap pancing tonda tidak mendapatkan hasil tangkapan tuna.

2. Komposisi plankton yang terdapat pada isi perut ikan tuna dan yang terdapat di perairan didominasi oleh
Genus Rhizosolenia dan Leptocylindricus yang merupakan indikasi kondisi perairan yang subur dan ikan tuna juga memakan plankton tersebut.

\subsection{Saran}

Rumpon portable efektif dan efisien untuk menangkap ikan tuna dan perlu dikembangkan bagi para nelayan rumpon di Indonesia dan perlu dilakukan penelitian secara terpadu lintas bidang di perikanan untuk pencapaian yang optimal dalam pemberdayaan masyarakat pesisir dan pengelolaan lingkungan. 


\section{DAFTAR PUSTAKA}

Barus, H. R., M. Linting, N. Naamin, S. Ilyas, M. Badrudin, C. Nasution, E. M. Amin, B. Gafa dan Sarjana. 1992. Pedoman Teknis Peningkatan Produksi dan Efisiensi melalui Penerapan Teknologi Rumpon. Departemen Pertanian Badan Penelitian dan Pengembangan Pertanian, Pusat Penelitian dan Pengembangan Perikanan. Jakarta. 87 hal.

Diniah, Monintja DR, Ardianto A. 2006. Teknologi Rumpon Laut Dalam sebagai Alat Bantu Pemanfaatan Sumberdaya Cakalang. Di dalam: Sondita MFA, Solihin I, editor. Buku Kumpulan Pemikiran Teknologi Perikanan Tangkap yang Bertanggungjawab. Bogor: FPIK IPB.

[FAO] Food and Agriculture Organization. 1995. Ketentuan Pelaksanaan Perikanan yang Bertanggungjawab. Diterjemahkan oleh Daniel R. Monintja dan M. Badrudin, 1996, Code of Conduct Product for Responsible Fisheries. Pusat Penelitian dan Pengembangan Perikanan, Jakarta. Hal. 43-47.

Herrera M. 2002. Catches of artisanal and industrial fleet in Indonesia: An update.WPTTO2-02, IOTC Proceedings No. 5.

Kantor Menteri Negara Lingkungan Hidup. 1998. Undang-undang Republik Indonesia No. 23 Tahun 1997 tentang Pengelolaan Lingkungan Hidup. 69 hal.
Monintja DR. 1990. Study on the development of rumpon as fish aggregating devices (FADs). Bul FPIK IPB. 3(2): 137.

Monintja DR, Zulkarnain. 1995. Analisis dampak pengoperasian rumpon tipe philippine di perairan zee terhadap perikanan cakalang di perairan teritorial Selatan Jawa dan Utara Sulawesi (laporan penelitian). Bogor: Fakultas Perikanan dan Ilmu Kelautan, Institut Pertanian Bogor.

Nurdin E. 2009. Perikanan tuna skala rakyat (small scale) di Prigi, Trenggalek Jawa Timur. Widya Riset Perikanan Tangkap 2(4): 177 183.

Yusfiandayani Roza. 1997. Studi Tentang Perikanan Mini Purse Seine Di Lempasing, Kecamatan Teluk Betung Barat Bandar Lampung Dan Prospek Pengembangannya [Skripsi]. Bogor: Departemen Pemanfaatan Sumberdaya Perikanan. Fakultas Perikanan dan Ilmu Kelautan. Institut Pertanian Bogor. 92 hal.

Yusfiandayani Roza. 2004. Studi Tentang Mekanisme Berkumpulnya Ikan Pelagis Kecil Di Sekitar Rumpon dan Pengembangannya Perikanan Di Perairan Pasaruan, Propinsi Banten [Disertasi]. Bogor: Program Studi Teknologi Kelautan. Institut Pertanian Bogor. 231 hal. 